\title{
Linear measurements of facial morphology using automatic aproach
}

\author{
Marijana Arapović-Savićn, Mirjana Umićević-Davidović ${ }^{1}$, Adriana Arbutina ${ }^{1}$, Mihajlo Savić ${ }^{2}$ \\ 'Department of Orthodontics, Study Program Dentistry, Faculty of Medicine, University of Banja Luka, Banja Luka, \\ Bosnia and Herzegovina; \\ ${ }^{2}$ Faculty of Electrical Engineering, University of Banja Luka, Banja Luka, Bosnia and Herzegovina
}

\begin{abstract}
SUMMARY
Introduction Clinical extraoral examination prior to orthodontic treatment includes face analysis (front and profile). Development of computer technology has increased efficacy and simplified this process through automating several steps of the analysis. The aim of this paper was to examine the possibility of automatic determining of linear measurements based on the facial image of a patient.

Material and Methods Based on the set of 20 patients in NHP (Natural Head Position) position, three sets of measurements were conducted. Trained orthodontist performed positioning of predefined points on the image of the patient two times with one week apart, after which the points were automatically determined using customized computer software. Based on the position of the points, measurements for bizygomatic distance, upper and lower facial height and full facial height were computed. Three sets of measurements were compared and statistically analyzed.

Results showed that computer software produced measurements comparable to measurements obtained by a trained orthodontist. Statistical analysis included calculating mean values and standard deviations, as well as paired two-tailed T-test. Differences between measurements ranged from $0.03 \%$ to $0.6 \%$ suggesting that automatic method can be successfully used.
\end{abstract}

Conclusions The results of this research suggest that it is possible to ease, accelerate and automate work of the orthodontist on the image analysis using suitable software without significant differences in measured values.

Keywords: computer analysis; standard analysis; frontal head photography

\section{INTRODUCTION}

Human face analysis represents both art and science. In order to assess the characteristics of human face, various measurements are used, such as: anthropometry, cephalometry and photogrammetry. Application of photogrammetry in orthodontics was first suggested by Stoner who compared profiles before and after the orthodontic treatment with ideal profiles [1]. Taking into consideration ethnic characteristics, gender, and age, it becomes clear that one culture's concept of beautiful and acceptable can be seen differently in other cultures $[2,3,4]$. By measuring facial soft tissues, as well as dentofacial ratios, standard reference values for different populations were determined $[5,6]$.

A number of orthodontic patients is interested in orthodontic therapy due to aesthetic disharmony. Such problems are easiest to observe and analyze on photographs [7]. Photographs represent auxiliary diagnostic method in orthodontics. They are used for proper diagnosis, treatment planning and treatment progress, tracking changes during growth and development, as well as an aid in communication with the patient. Photographs are also used for planning surgical treatment in orthodontics. Photographs have to be taken in standardized conditions, including predefined distance from lens to the patient, as well as standardized head position during imaging [8]. Photographs can also be used for educational purposes and for research. Digital technology has become an important element of clinical activities in orthodontic documentation. Digital extraoral and intraoral photographs can be imported into the software and presented together on the screen [9]. Photographs are part of proper documentation and visual reference for tracking changes in growth period. They are more understandable and selfexplanatory to patients compared to radiographic images. Making measurements from photographs is less invasive procedure for the patient and long lasting record that can be accessed at a later time $[10,11]$.

Determining positions of anthropological points and angles is necessary for precise determining deviation of normal. Anthropological analysis allows obtaining valuable information of the face characteristics. Proper choice and precisely determined reference points, regardless of method of analysis (manually or by a software) is of utmost importance for obtaining the exact measurements of angular and linear values [12].

The aim of this paper was to assess usability of computer software for automated quantifying of linear measurements of frontal face photography of the patient. 


\section{MATERIAL AND METHODS}

Measurements were performed on the set of 20 frontal face images in NHP (Natural Head Position) collected from various sources: 4 photographs from FEI set [13], 7 photographs of students of the University of Banja Luka and 9 publically accessible photographs of the models (in total 8 female and 12 male images). In order to make conditions more realistic for the computer software, dimensions of the photographs, position and relative face size were not the same on all photos.

Measurement points were chosen to fulfill two criteria: 1) most often used points in orthodontic analysis and 2) those that could be determined on two-dimensional image. Measurement procedure and data analysis were conducted based on the analysis performed by Bland and Douglas [14].

Reference measurement was done as described: positions of the following points on every image were determined by an orthodontist: N (Nasion), Sn (Subnasale), Gn (Gnation) and left and right Zg (Zigion). Measurements

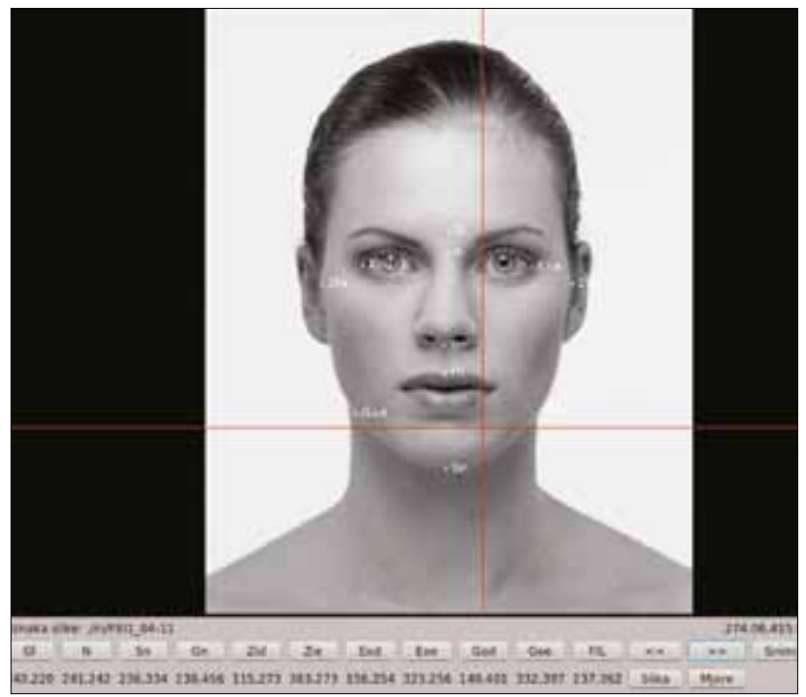

Figure 1. Work window of the computer software

Slika 1. Radni prozor kompjuterskog programa were repeated after one week. Based on those two measurements, the average position of every point was calculated and used as a third set of data. Figure 1 demonstrates the work window of used computer program.

After the initial manual measurements were done, the same points' positions were determined automatically by custom-made computer program. The program uses OpenCV (Open Computer Vision) [15] library for face detection, dlib [16] library and the predictor [17] that enables efficient detection of 68 reference points shown on the Figure 2. Based on those points, it is possible to determine positions of dependent points as well as required measurements. As all measurements were made in pixels, which real size varies between photographs, the program also calculates normalized values by dividing measured vertical distances (upper and lower facial height and total facial height) with bizygomatic distance (facial width). This approach required establishing correct position of $\mathrm{Zg}$ points first and whether the calculated values of bizygomatic distance were close to individually measured.

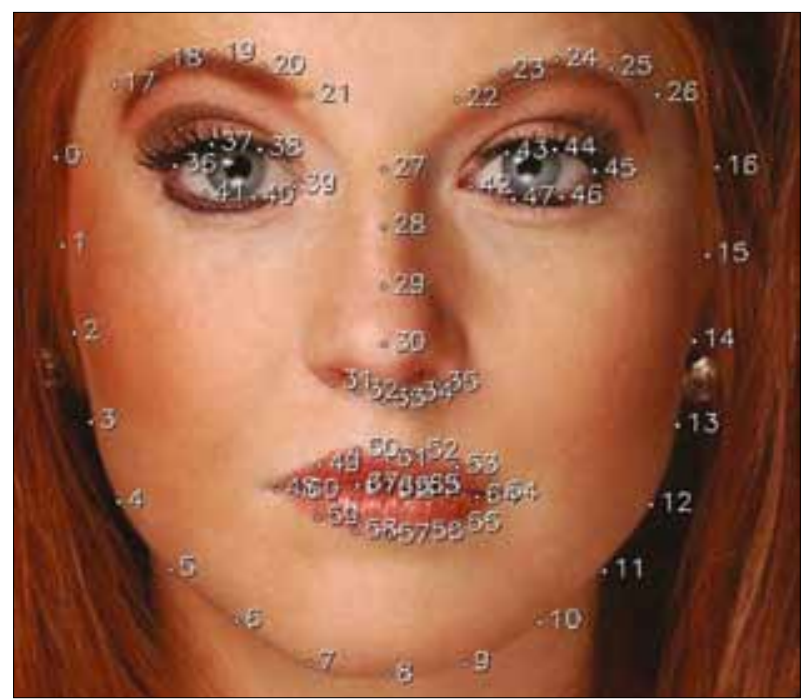

Figure 2. Positions of automatically determined 68 points Slika 2. Automatski određeno 68 tačaka

Table 1. Summary of measurements

Tabela 1. Sumarni pregled rezultata merenja

\begin{tabular}{|c|c|c|c|c|c|c|c|c|c|}
\hline \multirow{2}{*}{$\begin{array}{l}\text { Measurement } \\
\text { Merena veličina }\end{array}$} & \multicolumn{2}{|c|}{ Orthodontist Ortodont } & \multicolumn{2}{|l|}{ Program } & \multirow{2}{*}{$\begin{array}{c}\text { T-Test } \\
\text { p value } \\
\text { T-Test } \\
\text { P vrednost } \\
\end{array}$} & \multicolumn{2}{|c|}{$\begin{array}{l}\text { Orthodontist } 1 \\
\text { Ortodont } 1\end{array}$} & \multicolumn{2}{|c|}{$\begin{array}{c}\text { Orthodontist } 2 \\
\text { Ortodont } 2\end{array}$} \\
\hline & $\begin{array}{c}\text { Mean Value } \\
\text { Srednja vrednost }\end{array}$ & St. dev. & $\begin{array}{c}\text { Mean Value } \\
\text { Srednja vrednost }\end{array}$ & St. dev. & & $\begin{array}{c}\text { Mean Value } \\
\text { Srednja vrednost }\end{array}$ & St. dev. & $\begin{array}{c}\text { Mean Value } \\
\text { Srednja vrednost }\end{array}$ & St. dev. \\
\hline $\begin{array}{l}\text { Bizygomatic distance } \\
\text { Bizigomatično rastojanje }\end{array}$ & 241.38 & 37.89 & 241.45 & 37.06 & 0.92 & 241.20 & 37.72 & 241.55 & 38.10 \\
\hline $\begin{array}{l}\text { Upper facial height } \\
\text { Nosni sprat }\end{array}$ & 94.65 & 15.33 & 95.00 & 16.05 & 0.67 & 94.20 & 15.22 & 95.10 & 15.62 \\
\hline $\begin{array}{l}\text { Lower facial height } \\
\text { Dentalni sprat }\end{array}$ & 117.40 & 25.96 & 116.70 & 23.76 & 0.35 & 117.30 & 25.96 & 117.50 & 26.00 \\
\hline $\begin{array}{l}\text { Facial height } \\
\text { Visina lica }\end{array}$ & 212.05 & 38.96 & 211.70 & 38.42 & 0.50 & 211.50 & 38.67 & 212.60 & 39.33 \\
\hline $\begin{array}{l}\text { Norm. upper facial height } \\
\text { Norm. nosni sprat }\end{array}$ & 39.30 & 3.03 & 39.33 & 2.35 & 0.92 & 39.15 & 3.15 & 39.44 & 3.05 \\
\hline $\begin{array}{l}\text { Norm. lower facial height } \\
\text { Norm. dentalni sprat }\end{array}$ & 48.34 & 4.92 & 48.11 & 4.34 & 0.47 & 48.31 & 4.79 & 48.36 & 5.09 \\
\hline $\begin{array}{l}\text { Norm. facial height } \\
\text { Norm. visina lica }\end{array}$ & 87.64 & 5.45 & 87.45 & 5.27 & 0.56 & 87.46 & 5.16 & 87.81 & 5.82 \\
\hline
\end{tabular}


Obtained values were statistically analyzed and mean values and standard deviations were calculated for direct and normalized values. Paired two-tailed T-test was used and conclusions were made.

\section{RESULTS}

Table 1 shows summary overview of measured values with mean values, standard deviations and $p$ values of paired two-tailed T-test of average values measured by the orthodontist and computer. Differences of mean values for directly measured values ranged from $0.03 \%$ for bizygomatic distance, over $0.17 \%$ for facial height, $0.37 \%$ for upper facial height and $0.6 \%$ for lower facial height. Differences of means for normalized values ranged from $0.08 \%$ for upper facial height, over $0.22 \%$ for facial height to $0.48 \%$ for lower facial height. P values strongly suggested association between manually and automatically obtained measurements for every parameter.

Table 2 shows differences of mean values obtained for every measured parameters using manual (average of two measurements) and computer approach. Mean values for 4 parameters were smaller for automatic measurements, while values for 3 parameters were smaller for manual measurements.

Figures 3 to 6 give graphical representation of measured values as follows: blue line represents the mean values of two manual measurements, marks " + " and " $x$ " represent individual manual measurements and red circles represent automatic measurements. There is no qualitative difference between automatic and manual measurements for observed set of samples, which is in agreement with values in Tables 1 and 2 . There is a high level of correlation of measured values for bizygomatic distance obtained manually and automatically (Figure 3). Figure 4 shows measurements for facial height acquired manually and by the computer software. Differences in obtained values are minimal. Based on the Figure 5 that represents measurements for lower facial height, it can be seen that the differences are small while relatively larger discrepancies are present only with extreme values. Also, differences between manually and automatically obtained

Table 2. Differences of mean values

Tabela 2. Odstupanja srednjih vrednosti merenja

\begin{tabular}{|l|c|c|}
\hline $\begin{array}{l}\text { Measurement } \\
\text { Merenje }\end{array}$ & Program & $\begin{array}{c}\text { Orthodontist } \\
\text { Ortodont }\end{array}$ \\
\hline $\begin{array}{l}\text { Bizygomatic distance } \\
\text { Bizigomatično rastojanje }\end{array}$ & 0.08 & 0.18 \\
\hline $\begin{array}{l}\text { Upper facial height } \\
\text { Nosni sprat }\end{array}$ & 0.35 & 0.45 \\
\hline $\begin{array}{l}\text { Lower facial height } \\
\text { Dentalni sprat }\end{array}$ & -0.70 & 0.10 \\
\hline $\begin{array}{l}\text { Facial height } \\
\text { Visina lica }\end{array}$ & -0.35 & 0.55 \\
\hline $\begin{array}{l}\text { Norm. upper facial height } \\
\text { Norm. nosni sprat }\end{array}$ & 0.03 & 0.15 \\
\hline $\begin{array}{l}\text { Norm. lower facial height } \\
\text { Norm. dentalni sprat }\end{array}$ & -0.22 & 0.03 \\
\hline $\begin{array}{l}\text { Norm. facial height } \\
\text { Norm. visina lica }\end{array}$ & -0.19 & 0.17 \\
\hline
\end{tabular}

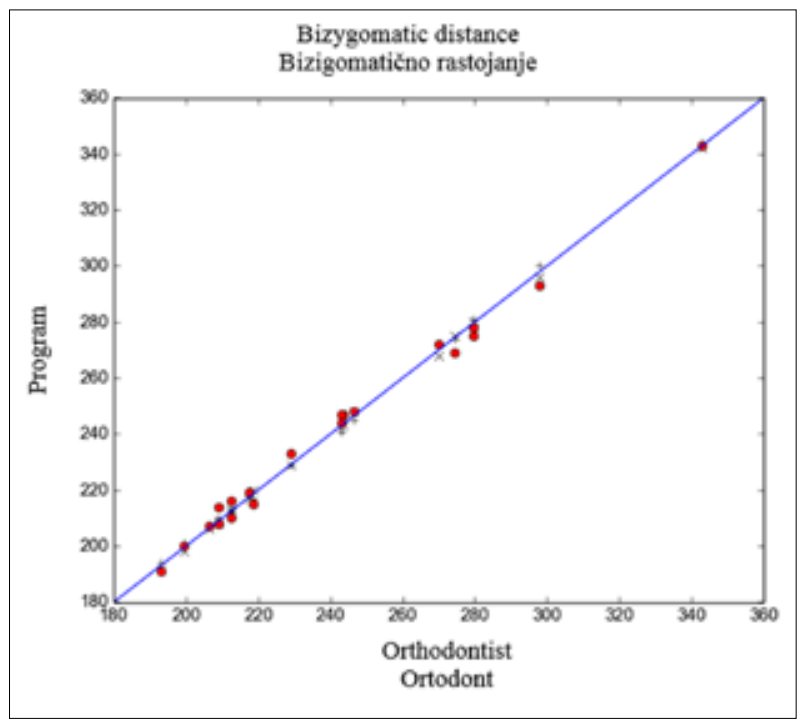

Figure 3. Bizygomatic distance

Slika 3. Vrednosti merenja za bizigomatično rastojanje

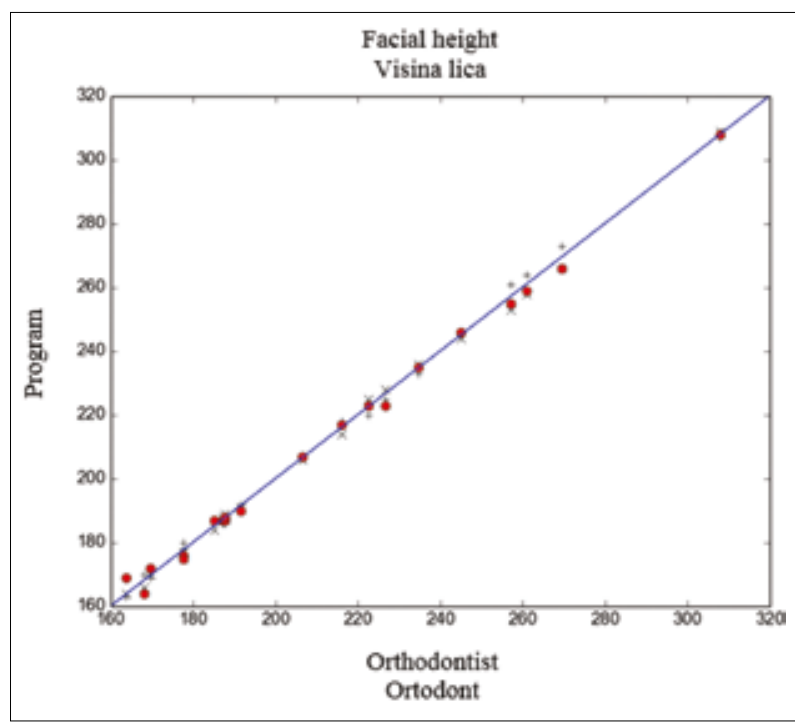

Figure 4. Facial height

Slika 4. Vrednosti merenja za visinu lica

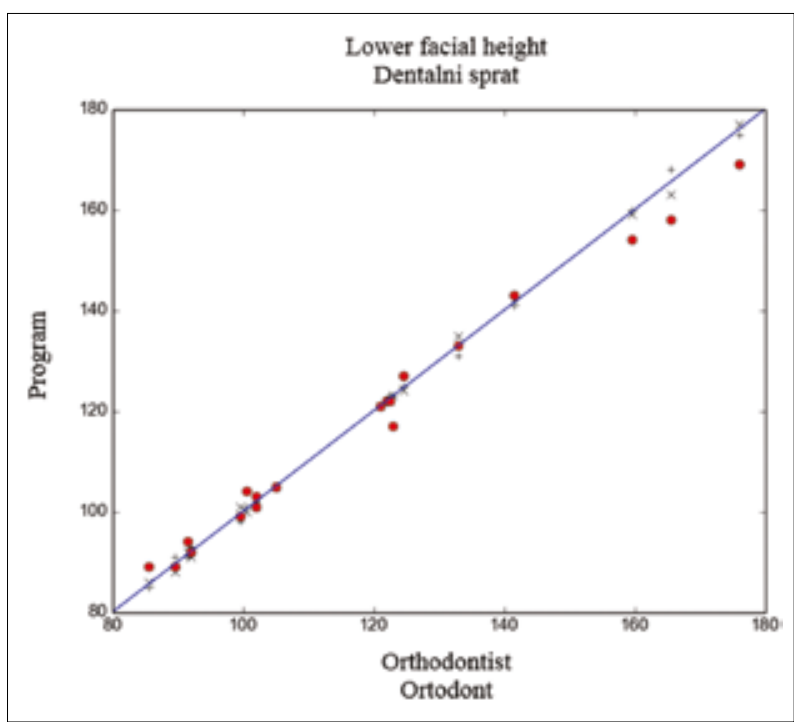

Figure 5. Lower facial height

Slika 5. Vrednosti merenja za dentalni sprat 
values for upper facial height are minimal, except for extreme values of measured parameters (Figure 6).

\section{DISCUSSION}

In clinical practice, but also in significant number of papers, one can observe the trend of automation of extraoral examination through the use of digital imaging and software that allows automatic calculation of various values based on reference points determined by an orthodontist [18-20]. Moshkelgosha et al. performed statistical analysis based on 27 points and 43 calculated values on the sample of 110 patients [18]. Aksu et al. analyzed the reliability of reference points in photogrammetry based on 9 measurements taken directly on 100 patients, as well as measurements determined by computer using facial images. After statistical analysis they concluded that reliability depends on gender and measured parameters [19]. Milutinović et al. compared standard and computer aided method of analysis of profile cephalogram on the sample of 32 patients. They found no statistically significant difference between the measurements obtained by the two methods with significant advantages in efficacy with computerized method [20].

On the other side, there is a widespread use of 3D scanners that enable generating and analysis of three-dimensional models of the patient's face with the possibility of automatic determining of the reference points for further analysis [21].

Over the course of multiple years of research Deli et al. identified problems related to automatic determining of the facial indicators. When reference indicators were projected on the faces or structured light approach used, the biggest problem has been shown to be low contrast between indicators and the skin of the patient [22]. Therefore, they concluded that the use of photogrammetry and multiple standard cameras were better solution compared to other approaches such as laser scanning and structured light [23]. The whole system included five precisely positioned digital cameras, predefined background with coded markers and light system. Differences from reference measurements were under $1 \%$ that was considered acceptable.

As indicator positioning directly on face is not an optimal approach, Loconsole et al. developed a method based on Microsoft Kinect device and custom made software for automatic determining of 11 points on the face [24]. During the research they used three methods of measurements - manually with digital two-pronged orthodontic caliper, automatic measurement based on the single recording and automatic measurement based on 100 successive recordings of the same face by averaging the values. Based on performed analysis they concluded that proposed method provided good results for nasion, subansale and left and right chelion. They identified problems with automatic measurements of the points that included palpation in manual measurements as well as the points that could not be precisely positioned in two-dimensional image (e.g. tip of the nose).
The proposed method for automatic determining of linear measurements of the face provided results comparable to measurements generated by standard manual method with no statistically significant difference. Therefore, it can be concluded that the use of automation in this case did not deteriorate the exactness of measurements, where on the other hand computer program was much faster in measuring than an orthodontist. The software is capable to position the points, calculate dependant parameters and analyze them for the time that human operator need just to select the image for analysis - about one second. Also, taking digital images is far cheaper and faster than generating 3D model of the face. Also patients are more familiar with digital imaging than 3D scanning.

Keeping in mind rapid advances in information technologies and mobile computing systems, it is expected in the near future to enable the smartphone or tablet for rapid determining of facial parameters of the patient and analysis of obtained data with improvements in interaction and cooperation with the patient.

\section{CONCLUSION}

The results of this research suggest that it is possible to ease, accelerate and automate the work of an orthodontist in the image analysis by using adequate supporting software without the significant differences in measured values.

\section{REFERENCES}

1. Stoner MM. A photometric analysis of the facial profile. Am J Orthod. 1955; 41: 453-469. [DOl: 10.1016/0002-9416(55)90156-1]

2. Fernández-Riveiro P, Suárez-Quintanilla D, Smyth-Chamosa E, SuárezCunqueiro $M$. Linear photogrammetric analysis of the soft tissue facial profile. Am J Orthod Dentofacial Orthop. 2002; 122(1):59-66. [DOl: $10.1067 / \bmod .2002 .125236$ ]

3. Fernández-Riveiro P, Smyth-Chamosa E, Suárez-Quintanilla D, Suárez-Cunqueiro M. Angular photogrammetric analysis of the soft tissue facial profile. Eur J Orthod. 2003; 25(4):393-399. [DOI: 10.1093/ ejo/25.4.393]

4. Bozkir MG, Karakas P, Oguz O. Vertical and horizontal neoclassical facial canons in Turkish young adults analysis of the soft tissue facial profile. Eur J Orthod. 2003; 25(3):212-219. [DOI: 10.1007/s00276-0030202-2]

5. Porter JP. The average African American male face: an anthropometric analysis. Arch Facial Plast Surg. 2004; 6(2):78-81. [DOl: 10.1001/ archfaci.6.2.78]

6. Choe KS, Sclafani AP, Litner JA, Yu GP, Romo T III. The Korean American woman's face: anthropometric measurements and quantitative analysis of facial aesthetics. Arch Facial Plast. Surg. 2004; 6(4):244-252. [DOI: 10.1001/archfaci.6.4.244]

7. Tanić T, Mllić J, Radojčić J. Uvod u osnovne principe dijagnostike i terapije u ortopediji vilica. Pančevo: Stomatološki fakultet, 2009.

8. Jakšić N, Šćepan I, Glišić B. Ortodontska dijagnostika, Beograd, 2004.

9. Anić-Milošević S, Šlaj M, Lapter-Varga M. Osnovna načela snimanja ekstraoralnih fotografija. Acta Stomatologica Croatica. 2005; 39(2):195-200.

10. Bishara SE, Jorgensen G), Jakobsen JR. Changes in facial dimensions assessed from lateral and frontal photographs. Part I-Methodology. Am J Orthod Dentofacial Orthop. 1995; 108(4):389-393. [DOl: 10.1016/S0889-5406(95)70036-6] 
11. Douglas TS. Image processing for craniofacial landmark identification and measurement: a review of photogrammetry and cephalometry. Comput Med Imaging Graph. 2004; 28(7):401-409. [DOI: 10.1016/j. compmedimag.2004.06.002]

12. Farkas LG, Katic MJ, Forrest CR, Alt KW, Bagic I, Baltadjiev G, et al. International anthropometric study of facial morphology in various ethnic groups/races. J Craniofac Surg. 2005; 16(4):615-646. [DOl: 10.1097/01.scs.0000171847.58031.9e] [PMID: 16077306]

13. Thomaz CE, Giraldi GA. A new ranking method for Principal Components Analysis and its application to face image analysis. Image Vision Comput. 2010; 28(6):902-913. [DOI: 10.1016/j.imavis.2009.11.005]

14. Bland JM, Douglas GA. Statistical methods for assessing agreement between two methods of clinical measurement. The Lancet. 1986; 327(8476):307-310. [DOI: 10.1016/S0140-6736(86)90837-8] [PMID: 2868172]

15. Bradski G, Kaehler A. Learning OpenCV: Computer vision with the OpenCV library. O’Reilly Media, Inc., 2008.

16. Ahonen T, Hadid A, Pietikainen M. Face description with local binary patterns: Application to face recognition. Pattern Analysis and Machine Intelligence, IEEE Transactions on. 2006; 28(12):2037-2041. [DOI: 10.1109/TPAMI.2006.244]

17. Kazemi V, Sullivan J. One millisecond face alignment with an ensemble of regression trees. Computer Vision and Pattern Recognition (CVPR), 2014 IEEE Conference on. 2014:1867-1874. [DOI: 10.1109/ CVPR.2014.241]

18. Moshkelgosha V, Fathinejad S, Pakizeh Z, Shamsa M, Golkari A. Photographic Facial Soft Tissue Analysis by Means of Linear and Angular Measurements in an Adolescent Persian Population. Open
Dent J. 2015; 9:346-356. [DOI: 10.2174/1874210601509010346] [PMID: 26464606]

19. Aksu M, Kaya D, Kocadereli I. Reliability of reference distances used in photogrammetry. Angle Orthodont. 2010; 80(4):670-677. [DOI: 10.2319/070309-372.1] [PMID: 20482352]

20. Milutinović J, Nedeljković N, Nikolić P. Uporedna analiza standardne i kompjuterske metode telerendgen dijagnostike u ortopediji vilica. Serb Dent J. 2006; 53(4):246-252. [DOI: 10.2298/SGS0604246M]

21. Kau CH, Richmond S, Zhurov Al, Knox J, Chestnutt I, Hartles F, et al. Reliability of measuring facial morphology with a 3-dimensional laser scanning system. Am J Orthod Dentofacial Orthop. 2005; 128(4):424430. [DOI: 10.1016/j.ajodo.2004.06.037] [PMID: 16214622]

22. Deli R, Di Gioia E, Galantucci LM, Percoco G. Automated landmark extraction for orthodontic measurement of faces using the 3-camera photogrammetry methodology. J Craniofac Surg. 2010; 21(1):87-93. [DOI: 10.1097/SCS.0b013e3181c3ba74]

23. Deli R, Galantucci LM, Laino A, D’Alessio R, Di Gioia E, Savastano $\mathrm{C}$, et al. Three-dimensional methodology for photogrammetric acquisition of the soft tissues of the face: a new clinical-instrumental protocol. Progress Orthodont. 2013; 14(1):1-15. [DOl: 10.1186/21961042-14-32] [PMID: 24325783]

24. Loconsole C, Barbosa N, Frisoli A, Orvalho VC. A new marker-less 3d kinect-based system for facial anthropometric measurements. InArticulated Motion and Deformable Objects; 7th International Conference, AMDO 2012; 2012:124-133. [DOI: 10.1007/978-3-64231567-1_12]

Received: 17.12.2015 - Accepted: 15.03.2016 


\title{
Automatsko određivanje linearnih veličina lica uz pomoć računara
}

\author{
Marijana Arapović-Savić ${ }^{1}$, Mirjana Umićević-Davidović1, Adriana Arbutina', Mihajlo Savić \\ ${ }^{1}$ Katedra za ortopediju vilica, Studijski program Stomatologija, Medicinski fakultet, Univerzitet u Banjoj Luci, Banja Luka, Bosna i \\ Hercegovina; \\ ²Elektrotehnički fakultet, Univerzitet u Banjoj Luci, Banja Luka, Bosna i Hercegovina
}

\begin{abstract}
KRATAK SADRŽAJ
Uvod Obavezan deo kliničkog ekstraoralnog pregleda ortodontskog pacijenta je analiza lica (anfas i profil). Razvojem računarske tehnike omogućeno je povećanje efikasnosti i olakšavanje rada ortodonata, ali i uvođenje automatizacije pojedinih koraka u ortodontskoj analizi. Cilj ovog rada je bio da se ispita mogućnost upotrebe programa za automatsko određivanje linearnih veličina lica na osnovu anfas fotografije pacijenta.

Materijal i metode rada Na uzorku od 20 fotografija ispitanika u NHP (Natural Head Position) položaju urađeno je tri vrste merenja. Obučeni ortodont je najpre odredio dva puta pozicije definisanih tačaka na digitalnoj fotografiji ispitanika sa pauzom od sedam dana, a nakon toga su pozicije ovih tačaka određene automatski upotrebom namenski razvijenog računarskog programa. Na osnovu dobijenih pozicija tačaka izračunate su vrednosti za bizigomatično rastojanje, visinu nosnog i dentalnog sprata, kao i za visinu lica. Dobijene vrednosti za tri vrste merenja su potom upoređivane i statistički obrađene.

Rezultati Statističkom obradom i upoređivanjem dobijenih rezultata uočeno je da namenski razvijen računarski program daje vrednosti uporedive sa vrednostima merenja obučenog ortodonta. Statistička obrada je uključivala računanje srednjih vrednosti $i$ standardnih devijacija, kao i sprovođenje uparenog obostranog T-testa. Odstupanja merenih veličina su se kretala od 0,03\% do 0,6\%, što predstavlja zadovoljavajući rezultat i sugeriše na opravdanu upotrebu automatske metode merenja.

Zaključak Rezultati ovog istraživanja sugerišu da je moguće olakšati, ubrzati i automatizovati rad ortodonata na analizi fotografija pacijenata upotrebom pogodnih programa bez značajnih odstupanja u vrednostima merenih veličina.

Ključne reči: računarska i standardna analiza; anfas snimak glave
\end{abstract}

\section{UVOD}

Analiza ljudskog lica predstavlja određenu vrstu umetnosti i nauke. Za procenu karakteristika ljudskog lica koriste se različita merenja kao što su: antropometrija, kefalometrija i fotogrametrija. Primenu fotogrametrije u ortodonciji je prvi put predložio Stoner, koji je poredio profile pre i posle ortodontskog tretmana sa idealnim profilima [1]. Uzimajući u obzir etničke karakteristike i pol, kao i promene koje nastaju zbog starosti, postaje jasno da ono što se smatra lepim i prihvatljivim kao norma za neke kulture, može biti različito za druge $[2,3,4$,$] . Merenjem$ lica, mekih tkiva, kao i dentofacijalnih odnosa, utvrđene su normalne referentne vrednosti u različitim populacijama $[5,6]$.

Najveći broj ortodontskih pacijenata zainteresovan je za ortodontsku terapiju zbog postojanja estetske disharmonije. Takvi problemi se najlakše uočavaju i analiziraju na fotografijama [7].

Fotografija predstavlja pomoćno dijagnostičko sredstvo u ortodontskoj dijagnostici. Ona pomaže pravilnoj dijagnostici, pomaže prilikom donošenja odluke o planu terapije, vrlo je pouzdana za praćenje toka terapije, za praćenje promena koje nastaju tokom rasta i razvoja, te kao pomoć u komunikaciji sa pacijentom. Fotografija se u ortodonciji koristi i pri planiranju ortodontsko-hirurškog lečenja pacijenta. Fotografije moraju biti pravljene pod standardizovanim uslovima, što podrazumeva određeno rastojanje pacijenta od objektiva, te standardizovan položaj glave prilikom fotografisanja [8]. Pored ovoga, fotografije se mogu upotrebljavati u nastavne svrhe i kao temelj za dalja istraživanja. Digitalna tehnologija iz dana u dan postaje sve važniji element u kliničkim aktivnostima, tako da i u ortodonciji raste upotreba digitalne tehnologije za ortodontske dokumente. Digitalne ortodontske ekstraoralne i intraoralne fotografije mogu biti odmah ubačene u programe i biti prikazane zajedno na ekranu [9]. Fotografija predstavlja mnogo konvencionalniju dokumentaciju i vizuelnu referencu za praćenje promena koje nastaju tokom rasta i razvoja. Pacijentima su pristupačnije i puno razumljivije od radiografskih snimaka. Merenja na fotografijama predstavljaju jednostavniju proceduru za pacijenta, a takođe pružaju trajni zapis lica kojem se može pristupiti i kasnije $[10,11]$.

Merenja određenih antropoloških tačaka i uglova na licu je neophodno za precizno određivanje odstupanja od normalnog. Obradom vrednosti nakon antropološke analize dobijaju se podaci koji predstavljaju vredne informacije o karakteristikama lica. Pravilan odabir i precizno određivanje referentnih tačaka, bilo da se analiza radi standardno ili računarski, od presudnog je značaja za tačnost dobijenih ugaonih i linearnih vrednosti [12].

Cilj ovog rada je bio da se ispita opravdanosti upotrebe programa za automatsko određivanje linearnih veličina lica dobijenih na osnovu anfas fotografije pacijenta.

\section{MATERIJAL I METODE}

Merenja su izvršena na skupu od dvadeset frontalnih fotografija ispitanika u NHP (Natural Head Position) položaju prikupljenih iz više izvora: četiri fotografije iz FEI skupa [13], sedam fotografija studenata Univerziteta u Banjoj Luci, te devet javno dostupnih fotografija modela, od čega je na fotografijama prisutno osam žena i 12 muškaraca. U cilju ostvarivanja realnih uslova za rad programa za automatsko određivanje tačaka, dimenzije fotografija, pozicija i relativna veličina lica nisu bile iste na svim fotografijama.

Tačke za merenje su odabrane tako da zadovoljavaju dva kriterijuma: najčešće korišćene tačke u ortodontskoj analizi lica, odnosno tačke koje je moguće odrediti na osnovu dvodimenzionalne fotografije. 
Procedura merenja i analiza rezultata su provedeni na osnovu analiza obavljenih od strane Blenda i Daglasa [14].

Referentno merenje je generisano na sledeći način: specijalista ortopedije vilica je upotrebom namenskog programa označio sledeće tačke na svakoj fotografiji: N (Nasion), Sn (Subnasale), Gn (Gnation), te levi i desni Zg (Zigion). Merenje je ponovljeno nakon sedam dana. Na osnovu ova dva merenja je izračunata srednja vrednost pozicije za svaku tačku, što predstavlja treću grupu podataka (Slika 1).

Nakon provedenih manuelnih merenja, iste tačke su određene automatski upotrebom namenski razvijenog programa. Program za funkcionisanje koristi OpenCV (Open Computer Vision) [15] biblioteku za detekciju lica na slici, dlib [16] biblioteku i prediktor [17], koji omogućava efikasnu detekciju 68 referentnih tačaka (Slika 2). Na osnovu tih tačaka je moguće odrediti lokacije zavisnih tačaka, kao i tražene veličine. Kako su vrednosti svih veličina izražene u tačkama čija realna veličina varira od slike do slike, pored direktnih vrednosti su izračunate i normalizovane vrednosti, koje su dobijene tako što je izvršeno deljenje izračunatih vertikalnih veličina (visina lica i spratova lica) bizigomatičnim rastojanjem (širinom lica). Ovaj pristup je diktirao da je pre svih ostalih analiza neophodno bilo proveriti da li je lokacija Zg tačaka pravilno određena i da li su izračunate vrednosti bizigomatičnog rastojanja bliske individualno merenim veličinama.

Dobijene vrednosti su nakon toga statistički obrađene i izračunate su srednje vrednosti i standardne devijacije za direktne i normalizovane vrednosti. Nakon toga je proveden i upareni dvostrani T-test.

\section{REZULTATI MERENJA}

U tabeli 1 prikazan je sumarni pregled merenih veličina sa srednjim vrednostima, standardnim devijacijama i vrednostima uparenog obostranog T-testa (p) sprovedenog na prosečnim vrednostima dobijenim od strane ortodonta i računara.

Kod direktno merenih vrednosti odstupanja srednjih vrednosti su se kretala između $0,03 \%$ za bizigomatično rastojanje, preko $0,17 \%$ za visinu lica i $0,37 \%$ za nosni sprat, odnosno $0,6 \%$ za dentalni sprat. Odstupanja srednjih vrednosti od normalizovanih vrednosti parametara su se kretala od $0,08 \%$ za nosni sprat, preko $0,22 \%$ za visinu lica i do $0,48 \%$ za dentalni sprat.

Dobijene vrijednosti (p) snažno sugerišu povezanost ručno merenih i automatski dobijenih vrednosti za svaki od merenih parametara.

Odstupanja srednjih vrednosti dobijenih ručnim merenjem i upotrebom programa za svaku od merenih veličina u odnosu na srednju vrednost dva ručna merenja prikazana su u tabeli 2.

Odstupanja srednjih vrednosti dobijenih ručnim merenjem i automatskim merenjem su u četiri slučaja manja za automatski merene vrednosti, a u tri slučaja manja kod ručno merenih vrednosti.

Na slikama 3 do 6 grafički su prikazane dobijene vrednosti merenja. Tako plava linija predstavlja srednje vrednosti ručnih merenja, oznake „+ $\mathrm{i}$, $\mathrm{x}$ “ predstavljaju pojedinačna ručna merenja, dok crveni krugovi predstavljaju automatski dobijene vrednosti. Sa slika je vidljivo da ne postoji kvalitativna razlika između automatski i ručno dobijenih vrednosti za posmatrani skup uzoraka.
Slika 3 pokazuje da postoji visok stepen poklapanja vrednosti bizigomatičnog rastojanja dobijenih ručnim merenjem i automatskim metodom, dok su na slici 4 prikazane vrednosti za visinu lica dobijene ručnim i računarskim merenjem sa minimalnim odstupanjima.

Vrednosti merenja za dentalni sprat su ukazala na mala odstupanja, dok su veća odstupanja zabeležena samo za ekstremne veličine (Slika 5).

Odstupanja između ručno i automatski dobijenih vrednosti za nosni sprat su takođe bila minimalna, osim za ekstremne vrednosti (Slika 6).

\section{DISKUSIJA}

U kliničkoj praksi je poslednjih godina u značajnom broju povećana primena računara u procesu ekstraoralnog kliničkog pregleda primenom digitalnih fotografija i programa koji omogućavaju merenje i izračunavanje potrebnih vrednosti na osnovu referentnih tačaka $[18,19,20]$. Moshkelgosha i saradnici su na osnovu računara i merenja 27 tačaka izračunavali 43 vrednosti kod 110 ispitanika [18]. Aksu, Kaya i Kocadereli su ispitivali pouzdanost referentnih udaljenosti na fotogrametrijama na osnovu merenja devet veličina direktno na licima 100 ispitanika, odnosno pomoću računara na fotografijama. Na osnovu statističke obrade rezultata zaključili su da pouzdanost merenja varira u zavisnosti od pola ispitanika i merenih veličina [19]. Milutinović i saradnici su upoređivali standardni i računarski metod analize profilnog telerendgen snimka glave na uzorku od 32 ispitanika. Na osnovu merenja i obrade rezultata zaključili su da nema statistički značajne razlike u vrednostima, ali uz značajne prednosti računarske metode [20].

S druge strane, upotreba 3D skenera omogućava generisanje i analizu trodimenzionalnih modela lica pacijenta na osnovu određivanja referentnih tačaka i vrednosti za analizu [21].

Višegodišnjim istraživanjima, Deli i saradnici su identifikovali osnovne probleme vezane za automatsko određivanje markera na licu pacijenta. Pri upotrebi projektovane mreže referentnih markera na lice pacijenta ili upotrebe strukturisanog svetla, najznačajniji problem je slab kontrast između markera i kože lica pacijenta [22]. U toku razvoja sistema autori su zaključili da je upotreba fotogrametrije i većeg broja standardnih fotografskih aparata pogodnije rešenje u odnosu na lasersko skeniranje ili upotrebu strukturisanog svetla [23]. Sam sistem se sastoji od skupa od pet digitalnih foto-aparata raspoređenih u prostoru, pozadine sa kodiranim markerima i sistema za osvetljenje. Odstupanja od referentnih merenja su lako prihvatljiva u praksi, jer su iznosila do $1 \%$.

Kako postavljanje markera na lice pacijenta nije optimalan pristup, Loconsole i saradnici su razvili metod za upotrebu Microsoft Kinect uređaja i namenski razvijenih softvera za automatsko određivanje 11 tačaka na licu [24]. U okviru istraživanja korišćena su tri metoda merenja - ručno (upotrebom digitalnog dvokrakog ortodontskog šestara), automatskog merenja na osnovu jednog snimka i automatskog merenja na osnovu 100 sukcesivnih snimaka istog lica. Autori su zaključili da predloženi metod daje dobre rezultate za nasion, subnasale, stomion, te levi i desni chelion. Identifikovani su problemi prisutni pri automatskom merenju tačaka koje nije moguće precizno pozicionirati u prostoru na osnovu dvodimenzionalne slike (npr. vrh nosa). 
Primenom programa za automatsko određivanje linearnih veličina lica dobijene su vrednosti koje su uporedive sa vrednostima koje je generisao standardni metod merenja i nisu zabeležena statistički bitna odstupanja. Upotreba računara utiče na tačnost podataka, ali je brzina i efikasnost ove metode mnogo veća. Naime, program je u stanju da izvrši određivanje tačaka, da izračuna izvedene vrednosti i izvrši analizu istih za vreme koje je ljudskom operateru potrebno samo za odabir fotografije za analizu - reda veličine jednog sekunda. Takođe, prednost opisanog rešenja u odnosu na 3D modele je u tome što je pravljenje digitalnih fotografija daleko jeftinije i brže od generisanja 3D modela lica pacijenta. Ne sme se zanemariti ni činjenica da pacijentima fotografisanje ne predstavlja nepoznanicu, dok je proces trodimenzionalnog skeniranja uglavnom nešto potpuno novo.
Imajući u vidu brzi razvoj informacionih tehnologija i prenosnih računarskih uređaja, u skorijoj budućnosti se može očekivati i upotreba mobilnog telefona ili tablet uređaja za brzo određivanje parametara lica i analizu dobijenih rezultata uz efikasniju interakciju i saradnju sa pacijentom.

\section{ZAKLJUČAK}

Dobijeni rezultati ovog istraživanja sugerišu da primena programa za automatsko određivanje linearnih veličina lica znatno olakšava, ubrzava rad ortodonata $u$ analizi fotografija pacijenata. Upotreba odgovarajućih programa ne dovodi do značajnih odstupanja u vrednostima merenja traženih parametara. 